\title{
Hygiene care - bath: meanings and perspectives of nurses
}

\author{
Cuidados de higiene - banho: significados e perspetivas dos enfermeiros \\ Cuidados de higiene - baño: significados y perspectivas de los enfermeros
}

Esmeralda Faria Fonseca*; Maria Helena de Oliveira Penaforte**;

Maria Manuela Ferreira Pereira da Silva Martins***

\begin{abstract}
Background: As direct care to the person, the bath, in its performance or supervision, is emphasised as a space/time of interaction and knowledge between the nurse and the person. However, it is sometimes regarded as merely the task of keeping a person clean.

Objectives: To understand the meaning assigned by nurses to hygiene care - bath; identify Nursing foci, related to the provision of Nursing care to the person as a whole, considered during hygiene care - bath; and describe the care provided during the bath. Methodology: Qualitative. A descriptive-exploratory, cross-sectional study was conducted with 18 participants using interviews and observation.

Results: The results indicate that the provision of health care - bath is a type of nursing care essential to body cleanliness and comfort, and offers an opportunity for communication, presence and relationship with the person. Different foci may be taken into account to guide the provision of care with a view to meeting the person's needs.

Conclusion: A type of care that promotes a space directed to the person and that must be provided by the nurse, who should encourage the person to have an active role in the care plan.
\end{abstract}

Keywords: hygiene; nursing care.

\section{Resumo}

Enquadramento: Como cuidado direto à pessoa, o banho, na sua execução ou supervisão, exalta-se como espaço/tempo de interação e conhecimento entre enfermeiro/pessoa. Porém, por vezes, é entendido como a tarefa de manter apenas a pessoa limpa.

Objetivos: Compreender o significado que os enfermeiros atribuem aos cuidados de higiene - banho; identificar os focos, relativos à pessoa no seu todo, que os enfermeiros consideram aquando da prestação do banho; e descrever o cuidado desenvolvido durante o banho.

Metodologia: Qualitativa. Estudo descritivo-exploratório, transversal, com recurso à entrevista e observação, com 18 participantes.

Resultados: Orientam-nos para a prestação dos cuidados de higiene - banho, como um cuidado de Enfermagem essencial à limpeza e conforto do corpo, sendo uma oportunidade para comunicação, presença e relação com a pessoa, onde se pode ter em conta focos que orientem a prestação de cuidados face às suas necessidades.

Conclusão: Um cuidado que potencia um espaço direcionado à pessoa, que deve ser efetuado pelo enfermeiro, incentivando-a na participação ativa do seu plano de cuidados.

Palavras-chave: higiene; cuidados de Enfermagem.

\footnotetext{
* MeSc., RN, Instituto das Irmãs Hospitaleiras do Sagrado Coração de Jesus - Casa de Saúde do Bom Jesus. 4715-308, Braga, Portugal [enf.esmeraldafonseca@live.com.pt]. Contribution to the article: article writing, bibliographic search, reading, and data analysis and discussion. Address for correspondence: Avenida do Sobreiral, $\mathrm{n}^{\circ}$. 161, Landim, 4715 038, Braga, Portugal.

** Ph.D., Medical-Surgical Nursing. Teacher, School of Nursing Dr. José Timóteo Montalvão Machado, 5400-673., Chaves, Portugal [nepenaforte@gmail.com]. Contribution to the article: bibliographic search, reading, and data analysis.

*** Ph.D., Clinical Nurse Specialist in Rehabilitation Nursing, 4200-450, Porto, Portugal [mmartins@esenfc.pt].Contribution to the article: supervisor - revision, correction, and guidance in article writing.
}

\section{Resumen}

Antecedentes: Como atención directa a la persona, el baño, es decir, su ejecución o supervisión, se muestra como el espacio/tiempo de interacción y conocimiento entre el enfermero y la persona. Sin embargo, a veces, solo se considera como la tarea de mantener a la persona limpia. Objetivos: Comprender el significado que los enfermeros atribuyen a los cuidados de higiene - baño; identificar los focos de la persona como un todo que los enfermeros consideran al dar el baño, y describir el cuidado llevado a cabo durante el baño.

Metodología: Cualitativa; estudio descriptivo-exploratorio y transversal en el que se recurrió a la entrevista y la observación con 18 participantes.

Resultados: Nos orientan a considerar que la prestación de los cuidados de higiene - baño es una atención de enfermería esencial para la limpieza y la comodidad del cuerpo y es una oportunidad para la comunicación, la presencia y la relación con la persona, en la que se pueden tener en cuenta focos que orienten la prestación de cuidados frente a las necesidades.

Conclusión: Una atención que potencia un espacio dirigido a la persona, que el enfermero debe realizar, fomentando que esta participe activamente en su plan de atención.

\section{Palabras clave: higiene; atención de enfermería.}

Received for publication: 19.09 .14

Accepted for publication: 05.02 .15 


\section{Introduction}

Hygiene is defined by the action "Performing: Bathing, changing clothes, personal turnout, associated with cultural patterns and socio-economic level" (Conselho Internacional de Enfermeiros, 2011, p. 96). The term hygiene embraces different areas that complement and expand its meaning, such as: collective hygiene, mental hygiene, occupational hygiene, public hygiene, social hygiene, home hygiene, food hygiene, body hygiene, among others (Martins, 2009). In the present study, the term hygiene is associated with the area of body hygiene, as a type of Nursing care Caring for the bygiene/Hygiene care.

In the reflection on Nursing care in any of its different conceptions, the focus is on caring for the individual according to his or her basic human needs. Understanding the essential things in a person's life, with a view to satisfying them, is the basic principle of Nursing care (Collière, 1989).

Taking into account that dependence in hygiene care - bath is mainly associated with impaired mobility (Silva, 2006), the nurse is the healthcare professional with the skills necessary to give patients a bath for this is an essential care for the human being, a life maintenance care (Collière, 1989) and a measure of health promotion and maintenance (Nightingale, 2005).

Throughout the procedure of hygiene care - bath, the experience between nurse/person goes beyond the technique. However, despite being object of research studies in different moments and praised as a fundamental of Nursing practice, the expansion of the work field brought about new and attractive interests focused on the delivery of care that require a greater degree of skill and judgement (Castledine, 2003; Henderson, 2007). As a result, hygiene care - bath moved from being a nurses' task to take second place and be delegated to support personnel (Fonseca, Penaforte, \& Martins, 2012; Mercadier, 2004).

There are indeed different perspectives towards hygiene care - bath. For some, it is a moment that offers space for continuity, bond and with meaning. For others, it is a repetitive, obsessive and meaningless action, in need of acts, empty of symbolic meaning, lost in the routines and simplicity (Penaforte, 2011). However, since nurses dismiss the time spent in providing or helping in hygiene care bath, a time when they could listen to the person and observe, they have to find other opportunities during their shifts to accurately assess their patients' needs (Henderson, 2007; Sandelowski, 2002).

The aim of this study was to understand the meaning assigned by nurses to hygiene care - bath; identify Nursing foci, related to the provision of Nursing care to the person as a whole, considered during hygiene care - bath; and describe the care delivered during the procedure of hygiene care - bath.

\section{Background}

In an analysis of the historical perspective of Nursing, Nightingale (2005) stated that personal hygiene was the essence of caring for the person. In addition to body cleanliness, it provided relief and comfort, establishing the daily hygiene of the body and the environment as a priority in Nursing education.

Hygiene care emerges as an autonomous and vital care of the discipline of Nursing (Downey \& Lloyd, 2008). It is represented by a set of practices aiming at body cleanliness and care, and contributes to the individual's general well-being, preservation, safety, comfort, and self-esteem maintenance (Potter \& Perry, 2006).

In view of the different actions in hygiene care, the bath emerges as a Nursing care practice (Henderson, 2007). In this way, the compound term is presented: bygiene care - bath specifying the intentional action performed by the nurse to the person.

During the undergraduate degree, the procedure for bathing is one of the most addressed topics at the beginning of training. However, the pedagogical method is limited to teaching and applying the technique, forgetting all of the entangled care processes present at that moment (Collière, 2003).

By requiring a direct and close contact with the person, hygiene care - bath is an opportunity for many other Nursing activities and interventions besides body cleanliness. They contribute to the development of the relationship and interaction nurse/person, creating an opportunity for sharing knowledge (Castledine; Martins, 2009, 2003), concerns regarding the care plan (Downey \& Lloyd, 2008), and evaluation, education and observation of the individual's physical and psychological state (Castledine, 2003; Corbin, 2008), and for other essential Nursing care to be initiated. 
However, in practice, hygiene care - bath is still seen as an accessory, in which the task is valued (Martins, 2009; Silva, 2006). Despite its complexity and evidence base, it is still seen as a simple and unimportant task (Fawcett, 2003; Nóbrega \& Silva, 2009). It is sometimes considered a routine moment, which is even performed without the nurse's involvement (Nóbrega \& Silva, 2009) and where the opportunity for intentional intervention to plan other care, teach and provide comfort and well-being to the person is lost (Fonseca et al., 2012).

Based on the connection between the different existing conceptions and given the lack of studies addressing the nurses' views on this subject, the following research questions were formulated.

\section{Research questions}

What is the meaning assigned by nurses to hygiene care - bath?

What are the Nursing foci, related to the provision of Nursing care to the person as a whole, considered during hygiene care - bath?

How do nurses act during hygiene care - bath and which aspects/needs are prioritised?

\section{Methodology}

Given the objectives and research questions, a qualitative descriptive-exploratory study was conducted.

Aware that the practice of hygiene care - bath acquires a contextual meaning in the hospital units, since it is there that the intervention is more often performed primarily by nurses, two Medical services of a Hospital Unit located in the Northern region of the Country were selected so that the participants could be observed while performing their tasks. It should be underlined that these services were selected for their high incidence and prevalence of people dependent on hygiene care-bath (Martins, 2009; Silva, 2006).

Through the non-probabilistic, intentional sampling method, and taking into account that sample size was chosen based on the quality of the data collected and its saturation, 18 participants were selected. It was observed that, as regards gender, most participants were female (72.2\%) with an average of 11.5 years in the profession, with a standard deviation of 7.64 , and 9.89 years of work in the service under analysis, with a standard deviation of 5.56. As regards the professional category, six were specialist nurses, two were specialist nurses and heads of service, and 10 were nurse practitioners.

With regard to the data collection method, two different instruments were chosen: semi structured interview and non-participant observation. The possibility of collecting data by means of two separate instruments allows complementing the observation of the practice of hygiene care - bath, with the data mentioned by the participants which would allow describing and comparing the results later on according to different perspectives.

Since this study set out to describe how the nurses act during the procedure of hygiene care - bath, for example if they take advantage of the moment to interact and pay attention to the person, an observation plan was drawn up based on the procedure described in the Manual de Normas de Enfermagem - Procedimentos Técnicos (Manual of Nursing Standards - Technical Procedures) (Veiga et al., 2010). This manual is accredited by the Central Administration of the Health System and the Ministry of Health, and has been proposed to be implemented in all Portuguese hospitals. The observation plan was a grid divided into eight moments, with an open space to register any facts that were being observed. The observations changed as the results from the observations were known, that is, our observation became more effective based on the ongoing results. Sixteen observations were made. The observations started when the nurse went to the patient's unit with the purpose of providing hygiene care - bath and ended when the nurse stored all the material used in the procedure with the intention to leave the ward. Each observation lasted on average 20 minutes, and the field notes were written immediately after the observation.

Given the need to obtain a larger set of information on the issue under analysis, semi-structured interviews were also conducted to establish a comparison between the participants' reports and their behaviours during the provision of hygiene care - bath. An interview script was drawn up in accordance with the study objectives and the previously formulated research questions. The interviews were performed during the nurse's shift, after the provision of hygiene care - bath, more precisely when the nurse agreed and 
had some free time to answer the questions. Eighteen interviews were performed, as the head nurses of the service were also included. Despite not being present during the delivery of direct care, their opinions were considered as essential. The interviews were audio recorded, so that the contents could be analysed in a reliable and sustained way.

Permission was requested from the hospital's Administration and Ethics Committee to conduct the study, safeguarding the ethical-legal aspects and the participants' informed consent.

As regards the analysis of data from both observations (which were grouped, synthesised, and identified by the letter 0 ) and transcribed interviews (identified by the letter $N$ ), these findings were first read by the authors based on the content analysis technique. The narratives were divided into similar categories and reorganised into similar groupings, which allowed assigning a meaning to the contents in the same categories in view of the phenomenon under study. So that the categories found could be reorganised and regrouped, the observations' field notes and interviews were once again read, question-byquestion, and line-by-line, resulting in an analysis grid with the regrouped and validated data. Data were regrouped based on the hypothesis that the more frequent is a characteristic, the more important it is for the study participants (Bardin, 2008). Categories and subcategories were thus created with the purpose of answering the abovementioned research questions.

\section{Results}

Based on the analysis of interview data, four distinct categories were identified (Figure 1). The first category is Bath, an instrument of care. A basic care that acquires the meaning of provision of hygiene care as essential to hygiene maintenance "The key meaning of the bath is to maintain the body hygiene ... to provide hygiene care" (N17), which provides the nurse an opportunity for evaluation "It is an important moment to evaluate the patient, ..." (N1) and intervene in the person "bath time is a good opportunity ... to exercise the patient's less active body parts ..." (N4), with a well-defined purpose of promoting comfort and relaxation "provide an immense comfort to the patient, ..." (N3) and "it's also a moment for patients to relax a little bit ..." (N1).

In the category Bath, a time for relationship, the bath acquires the meaning of opportunity for the nurse to meet the person, establish bonds of trust and accompany her/him in the care project, within a space of communication and presence "during the bath, the nurse has the opportunity to communicate with the patient ..." (N17); "it's the moment when you spend more time with the patient ..." (N13).

The category Bath, a process of care organisation also emerged. Bath is thus a means through which information can be collected and knowledge applied, with a view to establish a diagnosis "for me, bath time is one the most important moments to make a diagnosis, ..." (N7), provide care "the longest period of time that we spend with the patient and in which the patient is more exposed to our interventions." (N2) and assess the person's needs in a direct and organised manner "to evaluate the patient's mobility,deficits, ..." (N14).

They were also asked about the Nursing foci regarding the person as a whole which they take into account during the procedure. Hence the category Bath, $a$ moment of attention to the needs emerged. The most frequent Nursing foci were: skin; mobility; hygiene self-care; orientation; pain; ventilation "Hygiene selfcare, state of consciousness, pain, mobilisation ... almost all of them ..." (NO). 


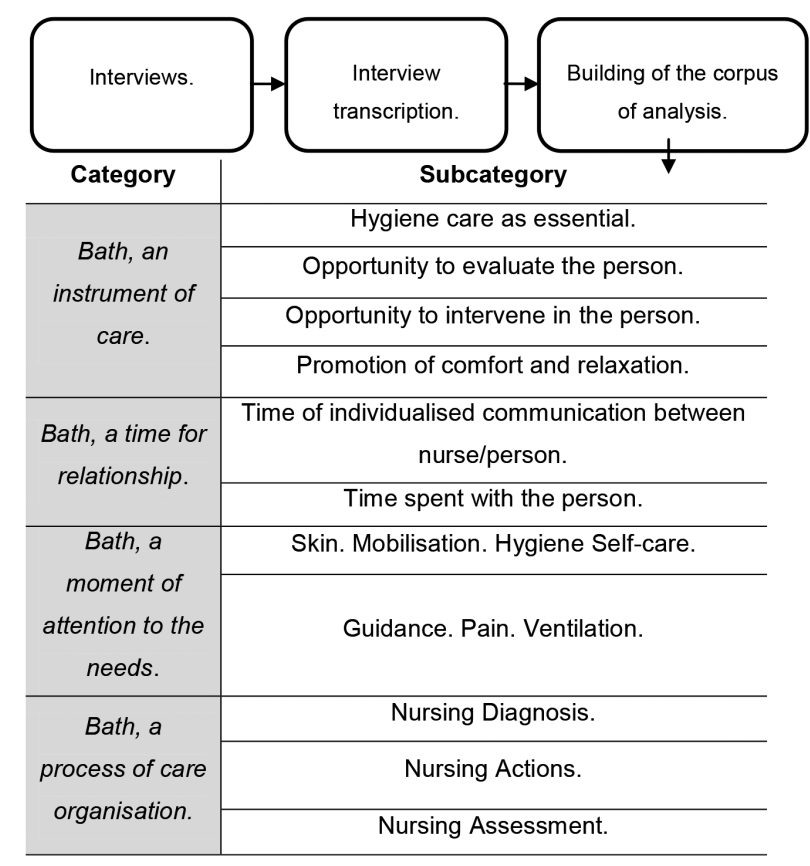

Figure 1. Diagram of data analysis: meaning assigned to hygiene care - bath.

Through the method of observation of the care provided during the bath, two categories were obtained (Figure 2). The first category is related to the care dynamics - Bath dynamics, divided into three distinct phases: approach and instruction of procedure, body care, and care execution.

The approach and instruction of procedure can be described in two different ways. The first one as a moment when nurses promote a space of communication/interaction to provide care "Nurse H. goes to Dona Carolina and says: "Good morning, Dona Carolina, how are you? Did you sleep well? Are you feeling good?" The nurse also asked: "Let's refresh a little bit ok? Is it ok?" The person said yes" (O2). On the other hand, nurses may also approach the person from the imperative perspective of care provision, in which there is no time available for procedure instruction. The latter is the most common situation observed. The nurse just "puts on the apron, grabs a basin with water, goes to Dona Gracinda and says: "Good morning", then lowers the bed and says: "I'm going to wash you now! ..." (06).

As regards body care, as described in the manuals, nurses care for the body during the bath in a sequential manner by undressing patients, washing them and drying the different body parts, applying cream and combing their hair: "[The nurse] starts by taking off the pyjamas ... they cover the body with a bed sheet and start the procedure. After washing the face, the nurses move on to washing the body in parts. ..." (O2; O3; O4; O5; O7; O8; O9; O10; O11; O12; 013; 014; 015).Thus, caring for the body during the bath results from regrouping a set of actions, justified by both the academic learning of the procedure and by the procedures imposed in the organisations or hospital services to be developed by the nurse when caring for the patient.

Care completion is characterised by ritualised actions, such as lifting the bed rails, arranging the bed sheets, storing the material, and organising the person's space. It can also be described in two different ways. There are those nurses who are more or less affectionate and show some concern: "[The nurse] cleans the material, washes the hands and says: "Ok, Dona Carolina, we're done, I will be right back ok? ..." (O2), or the nurses that: "Arranges the material, opens the curtains and leaves without saying goodbye to Dona Maria." (O0).

Also in the search for the meaning of the care provided during the bath, the category The person in the bath also emerged. It became clear that, during the procedure, the person may play two different roles: be an integral part of care or be a care receiver. As regards the patients' role as an integral part of care, 
their participation in their care was emphasised. Their partnership, their availability to collaborate in care provision are highlighted, "[The nurse] encourages her to collaborate: "Now please raise your left arm so that I can wash under the arm ... now your right arm ..." (O4). However, the following attitudes were also observed: "a parallel conversation between the nurses while both were applying the cream on the person's body, forgetting the person. There's no interaction between the nurse and the person ..." (O1). This shows the person's distance in relation to care. The person is seen as a mere passive receiver of care, subjected to side conversations with others and not with him/her during the bath, assuming a meaning in view of the person receiving care.

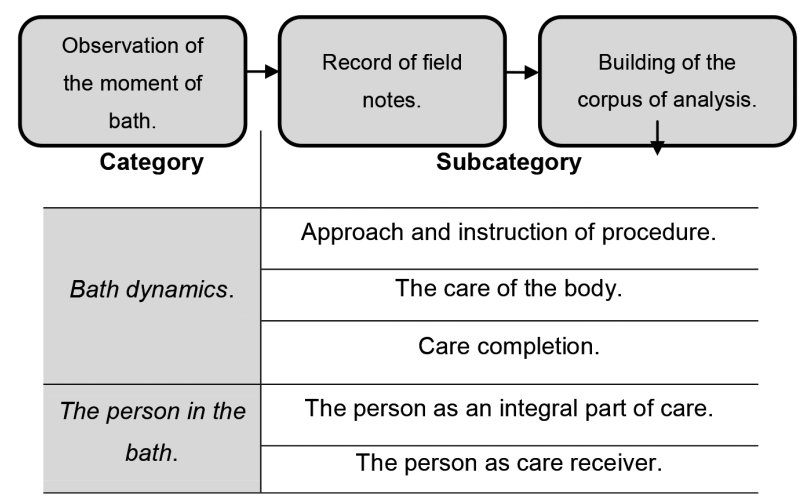

Figure 2. Diagram of data analysis: care delivered during the bath.

\section{Discussion}

In line with the literature, hygiene care - bath were considered as a way to keep a person clean, but were also a moment for active listening, communication, presence, sharing of knowledge, and interaction between the nurse and the person, thus contributing to the person's comfort and relaxation. As an instrument of care, we believe that these moments create an opportunity for the person's evaluation and intervention in the most frequently mentioned areas of attention (foci) by the nurses as priorities.

The bath dynamics in this study was described as being divided into three phases: beginning - Approach and instruction of procedure, development - Body care, and end - Care completion, which is in line with the division made by Penaforte (2011) in one of her works. A moment in which the person may be an integral part of care or a mere care receiver (category The person in the bath).

The person as an integral part of care, reflects that, in addition to his/her participation, the person acquires a sense of belonging to it. Hygiene care bath has here the meaning of time of presence next to the person. As the moment of hygiene care - bath is a moment of contact between the nurse and the person (Collière, 1989; Henderson, 2007), it allows the nurse to communicate with the person, and, through observation or touch, the nurse is able to interpret body condition, the physical, verbal and behavioural expressions, as well as adjust care, putting into practice the person's cognitive and affective skills (Martins, 2009).

However, the care related to the satisfaction of basic needs are often classified as too simple, not requiring any knowledge, mechanical and routine care which are often avoided by nurses (Nóbrega \& Silva, 2009). Aware of this, and although it was found that the nurses were aware of the set of care procedures that could be generated from the moment of hygiene care - bath, we wonder why it is not feasible as it is described in the literature.

Through the interviews' reports, the conclusion may be drawn that this is a result from a set of factors that interfere with the care delivered. The following Interferences during the bath were described: the medical visit "At the weekend is more quiet, there isn't the continuous coming and going of doctors, the changes ..." (N16); 
"we usually have much more things to do on a week day, we have the therapeutic changes, and if we think about it, it all together will take us more time and so our natural tendency is to try to gain a bit more time in hygiene care to have time to do the other things, ..." (N13), the complexity of the person's needs "it depends on the service, the number of patients in the service, and often the complexity of each one, ... there are times in which we are overloaded with work, ... we have very dependent patients who require much of our time and it's not always possible ..." (N10),

the ratio nurse/patient "there are times in which the service is overcrowded with dependent patients, and instead of giving two or three bed baths, we have to give four or five ...." (N3) and the material resources "we don't always have towels, we often have to clean them with the bed underpads, we don't always have pillows, we don't always have gowns, ..." (N12), which causes the nurses to be creative, and have good management and organisation skills, without losing sight of care.

We believe that these interferences may negatively influence the dynamics developed in hygiene care bath, making the nurse consider the person as a mere care receiver, giving more emphasis to the assistance or the performance of procedures that require greater technical complexity (Castledine, 2003; Fawcett, 2003).

Hygiene care - bath are seen only as an accessory care technique if their purpose focuses only on keeping the person clean. However, they will be considered as essential if, through this type of care, the nurse aims at enhancing the person's well-being, as according to Castledine (2003).

The results allow us to reflect on what the professionals say and what they actually do, knowing that this parallelism affects the construction and characterisation of care by those who receive it. It shows us that it is vital to learn and relearn Nursing care while the action of bathing is implemented by the nurse, humanising it. The stage for this care provision must be occupied by the nurse and the person, and performed as a means for health promotion since the nurses' initial training and throughout their career, through a constant update and interconnection of knowledge.

However, one of the study limitations was the existence of subjectivity. The analysis was based on the opinions of a group of nurses; however, this group may have been conditioned by factors that the researchers cannot control, such as the number of people admitted to the service at the time of data collection or the nurses allocated in the days of field work, given that only a small sample of a population was selected. Associated with this factor, the lack of data from other studies on this issue limited the study's theoretical background, as well as the comparison and discussion of results.

\section{Conclusion}

Hygiene care - bath constitute an opportunity for nurses to diagnose the needs that were most often mentioned by the nurses as priorities in their attention. Throughout the dynamics of hygiene care - bath, the person can play two different roles: be an integral part of care, actively participating in it, or being a mere care receiver. The person as an integral part acquires a sense of belonging to care. Here hygiene care - bath acquires the meaning of time of presence of the nurse with the person, where the nurse has the opportunity for individualised communication with the person and collect information that turn hygiene care - bath into an instrumental vehicle for different types of care. Given the abovementioned interferences at the time of hygiene care - bath, we believe that these factors may negatively influence the dynamics developed throughout the procedure, and may lead the nurse to consider the person as a mere care receiver in view of a set of needs which the nurse still has to meet.

Therefore, we conclude that hygiene care - bath are a vehicle for the provision of multiple Nursing care, which enrich the nurse's knowledge and value the nurse as caregiver.

The data from the characterisation of the admissions to the hospital units, particularly medicine units, shows us that the number of people dependent on care services increases. Therefore, being hygiene care - bath a basic human need that must be meet when the person is unable to perform it, which hygiene care - bath should be provided? Should nurses be the only ones providing it? Why do professionals delegate this care if they consider it a Nursing care in its implementation?

We are trying to prevent hospital units from being seen as cold places, devoid of human warmth. In this 
way, it is essential to rethink the provision of hygiene care - bath, preserving the direct care with the person. This study argues for the practice of a humanised care, not only by the nurse's simple action of giving a bath to the patient, but also due to the multiple care that this moment can generate in terms of caring for the person's needs in an individualised manner. Further studies on this issue should be developed focusing on the academic training of hygiene care - bath, the possible differences/advantages in the provision of hygiene care - bath as a type of care only provided by nurses, as well as on the ethical issues that nurses face as they are confronted with a naked person, which requires an adequate ethical and professional conduct.

\section{References}

Bardin, L. (2008). Análise de conteúdo. Lisboa, Portugal: Edições 70.

Castledine, G. (2003). Forgotten importance of giving a bed bath. British Journal of Nursing, 12(8), 519. doi: 10.12968/ bjon.2003.12.8.11266

Collière, M.-F. (1989). Promover a vida: Da prática das mulheres de virtude aos cuidados de enfermagem. Lisboa, Portugal: Sindicato dos Enfermeiros Portugueses.

Collière, M.-F. (2003). Cuidar . . a primeira arte da vida ( $2^{\mathrm{a}} \mathrm{ed}$.). Loures, Portugal: Lusociência.

Concelho Internacional de Enfermeiros. (2011). Classificação internacional para a prática de enfermagem CIPE: Versão 2. Genebra, Suiça: Autor.

Corbin, J. (2008). Is caring a lost art in nursing? International Journal of Nursing Studies, 45(2), 163-165.

Downey, L., \& Lloyd, H. (2008). Bed bathing patients in hospital. Nursing Standard, 22(34), 35-40.

Fawcett, J. (2003). Guest editorial: On bed baths and conceptual models of nursing. Journal of Advanced Nursing, 44(3), 229-230. doi: 10.1046/j.1365-2648.2003.02823.x
Fonseca, E. F., Penaforte, M. H., \& Martins, M. M. (2012). Caminhos para o conhecimento sobre o banho: Um aspeto relevante nos cuidados de enfermagem. Revista de Divulgação Cientifica: AICA, 4, 6-14.

Henderson, V. A. (2007). Princípios básicos dos cuidados de enfermagem do CIE. Loures, Portugal: Lusociência.

Martins, S. I. A. (2009). O banho no leito em contexto de internamento bospitalar: Vivências de pessoas idosas (Dissertação de mestrado). Retrieved from http://hdl.handle. net/10216/19116

Mercadier, C. (2004). O trabalbo emocional dos prestadores de cuidados em meio bospitalar: O corpo, âmago da interação prestador de cuidados-doente. Loures, Portugal: Lusociência.

Nightingale, F. (2005). Notas sobre enfermagem: O que é e o que não é. Loures, Portugal: Lusociência.

Nóbrega, S. S. da, \& Silva, L. W. S. (2009). Banho no leito, complexidade ou simplicidade: A ótica do olhar científico. In $61^{\circ}$ Congresso Brasileiro de Enfermagem: Transformação Social e Sustentabilidade Ambiental, Centro de Convenções do Ceará, Fortaleza Brasil, 08 Dezembro 2009. (pp. 1-18).

Penaforte, M. H. O. (2011). O Autocuidado de higiene: Conbecimento científico e ritual (Tese de doutoramento). Retrieved from http://repositorio.ul.pt/handle/10451/7342

Potter, P. A., \& Perry, A. G. (2006). Fundamentos de enfermagem: Conceitos e procedimentos ( $5^{\mathrm{a}}$ ed.), pp. 672-720 Loures, Portugal: Lusociência.

Sandelowski, M. (2002). Visible humans, vanishing bodies, and virtual nursing: Complications of life, presence, place, and identity. Advances in Nursing Science, 24(3), 58-70. doi: 10.1097/00012272-200203000-00007

Silva, M. J. M. R. (2006). Cuidados de bigiene: Intervenções dos enfermeiros a doentes internados num serviço de medicina (Dissertação de mestrado não publicada). Universidade do Porto, Instituto de Ciências Biomédicas Abel Salazar, Portugal.

Veiga, B. S., Henriques, E., Barata, F., Santos, F., Santos, I. S., Martins, M. M., ... Silva, P. C. (2010). Manual de normas de enfermagem: Procedimentos técnicos ( $3^{\mathrm{a}}$ ed.). Lisboa, Portugal: Ministério da Saúde. 

